\title{
STRATEGI INVESTASI DI BURSA SAHAM
}

\author{
Suryanto $^{1}$
}

\begin{abstract}
Investor uses strategy and a certain technique to analyze different situation and condition happened between one and other exchange companies. The strategy is developed based on experiences, research result, analysis, and market surveys in a certain period. Articel is the first part of three series which presents, evaluate, examine of the strategy, and consider tactics in sharing share on the market. It is concluded that the investor should use money as loan that should be payed as soon as possible for the sake of its interests.
\end{abstract}

Keywords: investation strategy, exchange and share on the market

\begin{abstract}
ABSTRAK
Para investor mengggunakan strategi dan teknik tertentu untuk menyiasati situasi dan kondisi yang berbeda antara satu bursa dengan bursa yang lain. Strategi tersebut dikembangkan berdasarkan pengalaman, hasil riset, analisis, dan pengamatan pasar dalam periode tertentu. Artikel ini merupakan bagian pertama dari trilogi yang memaparkan, mengevaluasi, menguji strategi, dan taktik bermain saham. Disimpulkan bahwa para investor sebaiknya menggunakan uang sebagai pinjaman yang harus dibayar secepat mungkin dengan bunga yang diharapkan.
\end{abstract}

Kata kunci: strategi investasi, bursa saham

\footnotetext{
${ }^{1}$ Staf Pengajar Fakultas Ekonomi, UBiNus, Jakarta
} 


\section{PENDAHULUAN}

Pesatnya pertumbuhan ekonomi memacu para pelaku menggunakan berbagai cara untuk memaksimalkan hasil usaha yang dilakukan. Para pelaku ekonomi melihat bahwa peningkatan hasil yang diperoleh di pasar tradisional mengalami keterlambatan dalam mencapai hasil maksimum sehingga berbagai upaya dilakukan melalui kemajuan teknologi. Lalu, lahirlah ide perkembangan surat berharga yang semakin mempercepat arus perdagangan di pasar modal.

Pelaku ekonomi yang selanjutnya disebut sebagai investor, berupaya untuk memaksimalkan hasil yang diinvestasikan dengan berbagai instrumen seperti analisis laporan keuangan dan teknik yang digunakan untuk melakukan tindakan investasi. Secara umum, banyak cara yang digunakan dan bersifat universal dalam investasi yang berlaku sepanjang masa. Dengan analisis laporan keuangan dan teknik yang digunakan, para pelaku pasar dapat memaksimalkan hasil investasi yang diharapkan. Banyak strategi yang digunakan untuk menghasilkan tingkat pengembalian maksimal dengan teknik yang dipakai seperti teknik January Effect. Teknik itu digunakan untuk menyiasati aspek perpajakan yang berlaku di Amerika namun tidak berlaku di Indonesia.

Dengan demikian, teknik yang dipakai sangat tergantung pada kebiasaan yang digunakan suatu pasar modal tertentu. Oleh karena itu, para pelaku pasar harus jeli melihat kecenderungan yang terjadi di pasar modal dan mengamati data statistik pergerakan saham sebelumnya kemudian menggabungkan berbagai faktor analisis untuk membuat keputusan investasi.

\section{PEMBAHASAN}

\section{Pengertian Investasi}

Pola mengembangkan kekayaan sudah dilakukan oleh orang di zaman dahulu hingga sekarang. Namun, terdapat beberapa hal yang membedakan pola pengembangan kekayaan zaman dahulu dengan sekarang. Pola pengembangan kekayaan zaman dulu yang berlangsung hingga sekarang ini ditujukan pada hal yang berbentuk fisik seperti tanah, gedung, ternak, kendaraan, mesin, dan segala hal yang berwujud. Pola pengembangan itu lebih dikenal dengan istilah investasi real assets. Namun dengan perkembangan dunia usaha dan pola berpikir dewasa ini, pola pengembangan kekayaan sudah mulai beralih, tidak hanya pada bidang yang berwujud tetapi sudah mulai beralih pada bidang surat berharga seperti deposito, obligasi, valas, maupun portofolio saham. Pola investasi itu lebih dikenal dengan financial assets.

Dari semua kegiatan yang dilakukan untuk menambah kekayaan, pada hakikatnya merupakan kegiatan investasi. Dengan kata lain, investasi merupakan upaya untuk mengalokasikan sejumlah dana pada salah satu atau beberapa wadah investasi yang tersedia dengan harapan memperoleh keuntungan. Pada investasi financial assets, dituntut untuk menginvestasikan waktu agar mendapatkan informasi yang terbaru dan konkret dalam melakukan investasi di pasar saham. Investasi di bursa saham membutuhkan pergerakan cepat dalam mendapatkan rumor yang benar serta keahlian tertentu dalam menjabarkan informasi dan laporan keuangan guna memaksimalkan hasil yang akan diperoleh. 


\section{Karakteristik Pasar Modal}

Sebelum melakukan investasi saham, sebaiknya diketahui karakteristik pasar modal khususnya pasar modal saham. Ciri pertama, seperti sifat perkiraan aktiva lancar yang lain, surat berharga seperti saham merupakan perkiraan yang bersifat liquid karena pasar setiap saat siap melakukan penjualan maupun pembelian.

Ciri kedua, penjual maupun pembeli mempunyai kesempatan yang sama untuk memperoleh informasi yang memadai melalui berbagai media informasi yang tersedia. Untuk memperoleh informasi yang konkret dan akurat, dibutuhkan kejelian dan usaha ekstra dalam mencari informsi guna melengkapi keputusan yang akan dibuat atas investasi kita. Melalui informasi tersebut, dapat ditafsirkan dampak informasi dan peristiwa yang sedang maupun akan terjadi atas pergerakan saham di bursa saham. Sebagai contoh, Bank Indonesia mengumumkan penurunan suku bunga pasar. Hal itu akan berdampak terhadap nilai indeks saham gabungan di bursa. Adanya penurunan suku bunga, berarti investasi yang dilakukan oleh para investor tidak akan sebesar yang diharapkan sebelumnya. Mereka cenderung mencari hasil investasi yang lebih besar lagi seperti saham yang mungkin akan membexrikan hasil berlipat ganda daripada bunga di bank. Hal seperti itu akan lebih dirasakan oleh pelaku pasar di negara maju yang sudah terbiasa dengan pasar modal. Selain negara maju, negara berkembang pun akan merasakan dampak penurunan suku bunga di Amerika karena banyak penanam modal asing yang berdagang saham di negara berkembang seperti Indonesia. Dengan banyaknya permintaan pembelian, secara otomatis akan menaikkan indeks harga saham secara keseluruhan.

Ciri ketiga dalam perdagangan saham, para pialang akan mengenakan biaya atas transaksi yang terjadi baik itu transaksi penjualan maupun pembelian dengan biaya yang cukup minim sebesar 0,3\% untuk transaksi pembelian saham dan 0,4\% untuk transaksi penjualan saham. Dengan biaya yang minim, diharapkan tidak menjadi beban bagi pelaku saham untuk menjual dan membeli saham dalam frekuensi yang cukup tinggi. Dengan demikian, perdagangan saham dapat diberdayakan untuk mendorong perputaran yang tinggi atas dana di pasar modal.

Ciri terakhir pasar modal adalah harga mengikuti informasi yang berkembang di pasar. Seperti hukum permintaan dan penawaran dalam ekonomi, semakin tinggi permintaan, mengakibatkan naiknya harga suatu objek dari nilai yang diperdagangkan. Di bursa saham, juga berlaku hal yang sama untuk perdagangan saham. Ketika banyak investor melakukan transaksi beli, pada saat itu akan terjadi kenaikan saham yang diperdagangkan dan secara tidak langsung mengangkat nilai saham gabungan.

\section{Pelaku Pasar Modal}

Pada bagian lain pasar modal, terdapat dua jenis pasar yang terjadi di bursa saham. Pertama, dikenal dengan pasar primer. Di pasar primer, terjadi penawaran yang dilakukan oleh perusahaan atas aset yang dimiliki kepada suatu sindikat penjamin yang bersedia menanggung semua risiko yang mungkin terjadi atas penjualan saham yang diterbitkan perusahaan yang akan go public untuk diperjualbelikan pada pasr sekunder. Perusahaan yang ingin go public, sebelum menerbitkan sahamnya ke pasar harus mendapatkan pemeriksaan dari Bapepam yang memastikan bahwa perusahaan yang bersangkutan memang sehat dan layak. Pemeriksaan berkaitan dengan peningkatan laba selama lima tahun terakhir, anggaran dasar dan anggaran rumah tangga, jumlah saham yang akan diterbitkan dan banyak lagi hal lain yang diperiksa berkaitan dengan persetujuan 
yang akan diberikan kepada perusahaan yang akan go public. Pada pasar ini, sindikat penjamin mendapatkan harga dari perusahaan yang ingin menjual saham IPO-nya di bursa saham dengan harga yang lebih murah atau dengan diskon tertentu. Setelah kesepakatan disetujui, sindikat penjamin baru menawarkan ke pasar sekunder. Penawaran saham dari sindikat penjamin kepada para pialang yang ada di bursa saham kepada masyarakat yang dikenal dengan nama pasar sekunder. Di pasar itu, seluruh lapisan masyarakat yang memiliki account pada para pialang dapat melakukan transaksi beli maupun jual melalui pialang yang telah terdaftar di bursa saham dengan dikenakan biaya transaksi atas kegiatan jual beli yang dilakukan.

\section{Sifat Investasi}

Melalui pialang itu, para pelaku pasar yang kemudian lebih dikenal lagi dengan istilah spekulator dan investor melakukan transaksi beli dan jual. Pada dasarnya disebut sebagai spekulator karena pelaku pasar yang hanya menempatkan modalnya untuk jangka waktu yang relatif pendek (sort term) dengan mengharapkan tingkat pengembalian yang relatif tinggi dari pergerakan harga pasar atau disebut tindakan profit taking untuk mengambil selisih harga jual terhadap harga beli yang lebih tinggi. Disebut sebagai investor Karena para pelaku pasar yang melakukan tindakan penyertaan modalnya untuk jangka waktu permanen (long term).

Melalui investasi itu, investor mengharapkan pertumbuhan deviden serta kenaikan harga yang lebih tinggi di masa mendatang. Misalnya, dengan rumus menghitung nilai harga saham bagi perusahaan yang pertumbuhan devidennya konstan di masa akan datang dengan rumus $\mathrm{P}=\mathrm{D}$ $(1+\mathrm{g}) /(\mathrm{Ks}-\mathrm{g})$. Namun, harus disadari bahwa rumus tersebut tidak berlaku untuk kondisi ekonomi dan politik Indonesia yang sedang tidak stabil. Secara manajemen, pola investasi jangka panjang dengan jumlah saham yang relatif besar (antara 30\% hingga di atas 50\%) mempunyai hak kendali atas perusahaan berdasarkan hak suara yang dimiliki. Hak para pemegang saham biasanya tunduk kepada hukum dan peraturan yang berlaku di negara bersangkutan. Melalui uraian tersebut, dapat dibedakan antara spekulator atau investor tetapi yang jelas kedua pelaku pasar itu menyertakan modal mereka di bursa saham.

\section{Teknik Analisis}

Bagi pelaku pasar yang bertujuan investasi jangka panjang, perlu melakukan kombinasi analisis fundamental maupun analisis teknikal. Melalui tingkat analisis yang teliti berdasarkan laporan keuangan perusahaan, dapat diketahui kondisi perusahaan. Dari hasil analisis keuangan yang dihasilkan serta rasio yang digunakan, dapat diinterpretasikan laporan keuangan dengan analisis teknikal menjadi informasi yang berguna dalam mengambil keputusan investasi yang tepat. Analisis teknikal ditujukan untuk investasi jangka pendek yang lebih banyak melihat dan mendengar perkembangan ekonomi maupun politik di luar dan dalam suatu negara serta kebijakan manajemen atau rumor yang ada dalam perusahaan bersangkutan.

\section{Strategi Investasi}

Untuk memperoleh hasil maksimal, harus dilihat berbagai segi baik perkembangan ekonomi maupun politik dalam dan luar negeri. Terdapat beberapa cara untuk memperoleh hasil yang maksimal seperti membeli saham di pasar primer dan dijual di pasar sekunder. Artinya, saham dibeli sebagai sindikat penjamin dan menjualnya melalui para pialang kepada masyarakat. Dengan cara itu, diperoleh keuntungan yang cukup besar melalui negosiasi dengan perusahaan 
yang akan meluncurkan saham IPO hingga 35\%. Untuk itu, diperlukan dana yang besar. Bila dana tidak memadai, dapat membeli saham di pasar sekunder dengan jumlah pembelian minimal 1 lot atau 500 lembar saham. Untuk membeli, harus diketahui kapan akan dibeli dan dijual.

Oleh karena itu, perlu menggunakan data terdahulu untuk mendapatkan nilai pembelian yang paling menguntungkan (paling rendah) dengan melihat kondisi pertumbuhan ekonomi yang diprediksi akan mengalami pertumbuhan dan kenaikan harga yang cukup memuaskan sesuai dengan margin yang diharapkan. Untuk mendapatkan hasil yang maksimal, harus bermain di sektor yang perkembangan berita maupun rumornya dapat menjanjikan hasil yang maksimal.

\section{Strategi Perdagangan}

Pada pelaksanaan perdagangan saham, terdapat beberapa hal yang harus diperhatikan. Hal itu berkaitan dengan pemilihan pialang yang terpercaya dan kuat, margin yang diharapkan, antisipasi kemungkinan hal terburuk yang akan terjadi, dan faktor psikologis.

\section{Pelaksanaan Perdagangan}

Contoh kasus, seorang investor pergi keluar kota. Dia menitipkan 90 lot saham dan uang sejumlah 20 juta rupiah kepada sebuah perusahaan efek lokal agar dapat tetap memberikan order transaksi dari luar Jakarta. Ketika kembali ke Jakarta, ia dikejutkan dengan raibnya saham dan uang yang dititipkan Karena perusahaan efek tersebut telah bangkrut (Kontan no. 41, tahun III, 12 Juli 1999). Hal itu hanya gambaran sebuah kasus investor yang dirugikan oleh pialang. Masih banyak kasus lain yang merugikan para investor. Oleh karena itu, para investor dituntut untuk berhati-hati dalam menyeleksi commission house, para dealer atau pialang.

Dengan demikian, kita dituntut untuk jeli mencari informasi tentang commission house yang berkompetensi penuh dalam memberikan rekomendasi untuk membeli saham tertentu yang menjanjikan keuntungan berlipat. Atas rekomendasi tersebut, kit apun harus menganalisis kembali rekomendasi yang diberikan dengan realita dan informasi yang kita peroleh, sampai kita yakin bahwa rekomendasi yang diberikan akan memberi keuntungan. Selain commission house, kita juga harus memilih pialang yang tepat dan sesuai dengan kebutuhan. Jika kita membutuhkan nasihat investasi, pilang yang mempunyai dukungan commission house yang dipilih. Bila ingin mempercayakan dana untuk dikelola pialang, pilihlah pialang yang berlisensi di bidang manajemen investasi. Jika ingin memperlancar investasi di pasar perdana, sebaiknya investor memilih pialang yang memiliki izin serta berpengalaman sebagai penjamin emisi.

Selain commission house dan pialang yang berpengalaman, perlu diperhatikan fasilitas dan sistem operasinya. Kita harus melihat apakah boot yang dimiliki di lantai bursa cukup banyak untuk mengeksekusi pesanan dari pelanggan dengan cepat dan apakah back office sistem yang dimiliki pialang sudah memadai dan mampu menangani semua transaksi dengan baik.

Hal yang tidak kalah pentingnya adalah struktur modal. Mungkin Anda bertanya untuk apa modal besar diperlukan oleh pialang. Bukankah pialang beroperasi dengan dana nasabah dan mendapat komisi. Masalahnya, pialang yang bermodal besar dapat menawarkan fasilitas yang lebih lengkap seperti mempekerjakan tenaga analis yang lebih banyak dan berpengalaman. Lengkapnya fasilitas yang disediakan berarti kecepatan transaksi dan pembukaan account lebih mudah dilakukan. 


\section{Margin Perdagangan}

Hasil dan risiko investasi bagaikan dua sisi mata uang. Merupakan hal yang tidak realistis untuk menginginkan hasil tetapi tidak bersedia menanggung risiko investasi. Harus disadari bahwa harapan setiap investasi adalah apa yang akan dihasilkan hari esok, apakah itu bunga, deviden, capital gain, atau laba usaha langsung. Tidak ada jaminan investor akan memperoleh hasil seperti yang diharapkan. Bunga bank dapat digerogoti inflasi, perusahaan dapat gagal mencetak laba, dan harga saham dapat menurun.

Para investor harus realistis dalam berinvestasi. Agar tujuan investasi tercapai, harus dibuat rencana investasi yang sesuai dengan kondisi finansial yang tersedia. Contohnya berapa hasil investasi yang diharapkan dan berapa lama waktu yang tersedia untuk mencapai tujuan dan saran investasi yang dipilih. Untuk itu, dapat dilakukan pembelian saham satt IHSG sedang turun karena mungkin memperoleh keuntungan.

Teknik lain mendapat keuntungan dengan membeli saham saat di pasar ada rumor atau isu yang berkembang tentang pembenahan manajemen atau tindakan akuisisi maupun merger yang mungkin digunakan. Pada saat ini, umumnya akan menaikkan nilai pasar dari saham yang diperdagangkan. Kemudian, harga saham akan turun ketika kegiatan manajerial telah dipublikasikan. Keuntungan dapat terealisasi bila harga yang diperkirakan tinggi.

Harus diwaspadai bila harga mengalami penurunan. Untuk itu, perlu dilakukan diversifikasi dengan cara membagi investasi di beberapa sektor yang berprospek baik. Langkah itu dilakukan untuk mengantisipasi kemungkinan terburuk pasar terhadap perdagangan saham di bursa efek. Jika salah satu saham mengalami penurunan harga, perputaran semua dana investasi tidak terhenti karena dapat berdagang saham di sektor lain yang harganya mengalami kenaikan. Dengan demikian, telah dilakukan pembagian risiko. Dalam menerapkan kebijakan investasi, hendaknya investor memilih saham yang memberi hasil sesuai dengan tujuan. Berdasarkan potensi hasil itu, kategori saham terdiri dari empat, yaitu income stock, growth stock, total return stock, dan speculative stock.

Income stock merupakan saham emiten yang mempunyai kebijakan pembayaran deviden yang relatif tinggi dan konsisten. Investor hendaknya melihat pertumbuhan deviden yang dibayarkan selama sedikitnya lima tahun ke belakang. Jenis saham itu merupakan saham yang paling rendah risikonya. Untuk growth stock, investor lebih mengutamakan pertumbuhan pendapatan dan laba emiten daripada pertumbuhan deviden. Untuk melihat risiko growth stock, investor dapt membandingkan kinerja portofolio dengan tolok ukur (benchmark) yang dievaluasi setahun sekali atau tiga bulan sekali.

Total return stock merupakan saham yang membagi deviden dan mempunyai pertumbuhan harga saham yang baik. Itu termasuk saham jenis blue chip yang mempunyai pergerakan saham dan volume yang cepat. Saham speculative stock berpotensi memberi keuntungan besar dalam tempo singkat seperti saham baru dan emiten di bidang industri yang sedang dalam tahap pengembangan. Untuk investasi spekulatif, kesulitan terbesar menjaga laju pasar yang berubah karena peluang akan muncul dan hilang dalam beberapa menit saja. 


\section{Psikologis Perdagangan}

Dari serangkaian transaksi yang dilakukan, para pelaku pasar mungkin akan terkena dampak psikologis seperti tingginya harapan pelaku pasar agar harga saham pasar mengalami kenaikan. Namun bila harapan yang dinanti-nantikan tidak terwujud, akan mengalami kekecewaan. Kekecewaan itu menimbulkan kecemasan yang berlarut-larut. Semua itu terjadi karena sifat serakah yang terdapat pada perilaku pasar. Itu merupakan suatu keserakahan yang harus dihindari untuk mengelak kerugian. Hal lain yang biasa terjadi pada pelaku pasar adalah sikap terlalu bangga dengan hasil yang pernah diperoleh. Karena dahulu pernah memperoleh keuntungan yang cukup besar, sekarang menginginkan hal yang sama sehingga merugi. Kecenderungan yang sering terjadi pada pelaku pasar, yakni mengikuti arus pasar.

Banyak yang membeli saham tertentu tanpa menganalisis dan mencari informasi yang memadai. Padahal, hal itu akan berisikio gagal lebih besar seperti terbawa arus turun naiknya harga untuk jangka waktu yang lama.

\section{Taktik Perdagangan}

Untuk meyikapi berbagai dampak psikologis perdagangan, kerugian yang terjadi dapat dibatasi. Caranya mencari saham yang dapat memberi capital gain. Jika harga saham turun, yang harus dilakukan menjual saham itu di saat yang tepat. Ganti saham tersebut dengan saham lain yang diperkirakan akan memberikan keuntungan. Dalam melakukan transaksi, para pelaku pasar harus menganalisis rasio risiko dan tingkat pengembalian untuk menentukan keuntungan dan kerugian yang akan terjadi. Hal ini akan melatih kedisiplinan mereka. Untuk itu, perlu ditentukan waktu perdagangan yang tepat untuk memaksimalkan laba dan meminimalkan rugi.

Dalam bertransaksi, perlu disadari modal yang tersedia untuk menenmpatkan porsi yang sesuai jumlah modal yang ada. Untuk itu, terdapat beberapa asumsi yang digunakan untuk perhitungan komposisi investasi. Investasi sebaiknya memakai dana yang telah disisihkan. Bila terjadi kerugian atau penurunan harga, tidak akan mempengaruhi kebutuhan sehari-hari. Dengan menajemen dana, dapat dihindari pengorbanan tidak terduga akibat kebutuhan mendadak.

\section{Kesalahan Umum dalam Investasi}

Banyak pelaku pasar yang hanya mengikuti pergerakan arus pasar tanpa melakukan analisis pasar yang lebih menyeluruh seperti laporan keuangan maupun isu yang sedang berkembang di pasar. Jika tidak dilakukan, hal itu akan menjadi hambatan dalam memperoleh keuntungan maksimal. Untuk itu, perlu dihindari perilaku mengekor pasar karena ada kemungkinan akan terjebak situasi saat harga saham mulai naik dan seorang investor baru masuk, pada saat itu mungkin pelaku pasar lain sudah melakukan profit taking.

Bukan hal realistis jika investor menolak kerugian. Dalam berinvestasi, pasti terdapat risiko merugi atau untung sehingga perlu diantisipasi sejak awal. Banyak pelaku pasar yang mengalami goncangan jiwa ketika mengalami kerugian akibat merosotnya harga saham. Untuk itu, mereka perlu berbesar hati dalam menghadapi keadaan terburuk.

Selain realistis, para pelaku pasar juga harus mempunyai analisis akurat untuk menentukan return yang diperoleh. Jika tidak dilakukan, capital gain yang didapat tidak maksimal 
yang dikenal dengan istilah asal untung. Jika perilaku pasar tidak menguntungkan, para pelaku pasar harus berubah haluan untuk menghindari kerugian yang lebih besar. Hal itu harus dilakukan dan jangan terlalu percaya diri dengan analisis awal yang telah dilakukan karena mungkin saja hasil analisis tersebut tidak didukung situasi politik dan ekonomi yang stabil. Untuk membaca keadaan, pelaku pasar dapat menggunakan hati nurani dalam berinvestasi. Hati nurani kadang kala akan memberikan pergerakan tersendiri terhadap keadaan yang sedang terjadi di pasar regional maupun nasional untuk transaksi jual beli. Agar hasil investasi yang ditanam memberi nilai maksimal, dibutuhkan konsentrasi yang cukup untuk terus memantau dan mendapat informasi yang berkembang di pasar. Dengan demikian, para pelaku pasar harus berfokus pada sektor tertentu saja untuk menghindari pecahnya perhatian atau konsentrasi terhadap informasi yang sedang berkembang. Tujuannya mengurangi kerugian dan memaksimalkan keuntungan.

\section{PENUTUP}

\section{Simpulan}

Kebijakan konvensional mengatakan bahwa investasi hendaknya dimulai dengan menetapkan tujuan, yakni harapan yang didefibisikan dengan spesifik. Tujuan investasi sangat beragam mulai dari menghimpun dana tertentu untuk bekal pensiun, biaya pendidikan anak, membeli rumah, mobil, atau yang lainnya guna menghasilkan pertambahan misalnya 20\% setahun. Tujuan investasi harus realistis agar mudah diwujudkan. Tidaklah realistis jika mengharapkan hasil investasi puluhan kali lipat dalam sebulan seperti menang lotere. Demikian juga kalau menginginkan capital gain di bursa saham, investor harus siap menerima capital loss.

Investor hendaknya bersikap prudent dan membuat rencana investasi yang sesuai dengan kondisi finansial yang ada, berapa hasil investasi yang diharapkan, berapa waktu yang tersedia untuk mencapai tujuan serta sarana investasi yang dipilih. Dalam menerapkan kebijakan investasi, sebaiknya investor memilih saham yang sesuai dengan tujuan. Berdasarkan potensi hasil itu, saham dapat digolongkan menjadi empat kategori, yakni income stock, growth stock, total return stock, dan speculative stock.

Dengan menentukan tujuan investasi yang baik, membuat aktivitas investasi lebih mudah. Keputusan untuk membeli atau menjual saham menjadi lebih mudah Karena hanya perlu mencocokkan apakah saham tertentu cocok dengan tujuan. Jika tidak cocok, jangan dibeli. Jika saham yang dibeli mempunyai kinerja di bawah target atau tolok ukur, investor dapat menjual saham tersebut dan membeli saham lain. Memilih satu atau beberapa ratusan saham merupakan pekerjaan yang melelahkan, memakan waktu, tenaga, dan biaya. Begitu pula halnya dengan proses pemantauan dan evaluasi portofolio. Jika investor tidak mempunyai waktu yang cukup, sebaiknya diserahkan kepada manajer investasi professional atau melakukan investasi melalui unit penyertaan reksadana saham.

Masalah yang sering dihadapi oleh semua simpanan dan investasi adalah darurat dan situasi lain yang memerlukan dana. Kondisi itu sering mengganggu simpanan atau investasi seseorang. Jika tidak dapat dihindari, sebaiknya investor memperlakukan penggunaan uang sebagai pinjaman yang harus dibayar secepat mungkin dengan bunga yang diharapkan. Dengan 
cara itu, mereka dipacu untuk tidak lengah dan selalu waspada terhadap setiap pergolakan situasi pasar.

\section{DAFTAR PUSTAKA}

Bodie, Marcus Kane. 1999. Investments. Edisi 4. McGraw-Hill.

Cahyono. 2000. 22 Strategi dan Teknik Meraih Untung di Bursa Saham. Jilid 1. Jakarta: Gramedia.

Kontan. 1999. No. 41 Tahun III, 12 Juli.

Weston. 1992. Manajemen Keuangan. Jilid 2. Edisi 8. Bina Rupa Aksara. 